JUDUL 4

\title{
PENGGUNAAN PUING BETON DAN KAPUR SEBAGAI LAPIS PERKERASAN PONDASI ATAS (BASE COURSE) JALAN
}

\author{
Mohamad Idrus, Daryati, Nira Nasution
}

\begin{abstract}
This research aim to know difference assess CBR materials base course the using material by exploiting concrete debris waste from rest of object test crushing test and lime with addition variation of lime equal to $0 \%, 10 \%, 12,5 \%$ and $15 \%$. This research also aim to know, do CBR materials base course by using concrete debris materials and lime can according to CBR standard value Bina Marga equal to $80 \%$.
\end{abstract}

This research use experiment method, population in this research is materials base course of road. The Sampel is object test from concrete debris materials and lime with mixture variation of lime $0 \%, 10 \%, 12,5 \%, 15 \%$. Each Variation is 4 example of test. Assess CBR obtained from CBR laboratory test.

From result of data analysis conclude that there are signifikan difference every mixture variation of concrete debris materials and lime. Result of $t$ test express that CBR materials value of base course by using concrete debris and lime bigger than CBR standard value Bina Marga ( $80 \%$ )

The Conclusion of this research is that usage of concrete debris and lime with concrete debris variation $85 \%$ and lime $15 \%$ yielding higher level CBR value from CBR value Bina Marga (80\%)

\section{PENDAHULUAN}

Seiring perkembangan teknologi sekarang ini, kebutuhan akan jalan sebagai prasarana transportasi sangatlah penting sebagai salah satu faktor utama dalam menunjang perekonomian suatu daerah. Hal ini mendorong pemerintah untuk meningkatkan pembangunan infrastruktur di bidang jalan raya, baik secara kualitas maupun kuantitas jalan raya tersebut.

Dilain pihak pembangunan jalan raya pada saat ini dihadapkan pada berbagai macam kendala, salah satu kendala yang sering dihadapi adalah keterbatasan bahan material jalan, dimana kita 
sering menghadapi kenyataan bahwa proyek pembuatan jalan membutuhkan material bahan konstruksi yang jumlahnya tidak sedikit. Oleh karena itu perlu diupayakan penelitian untuk mencari bahan alternatif sebagai pengganti material alami yang mungkin pada suatu saat nanti akan semakin berkurang jumlahnya.

Dari hasil pengamatan penulis, bahwa adanya penumpukan puing beton sisa dari pengujian crushing test beton merupakan bahan sisa yang dimungkinkan dapat dimanfaatkan sebagai bahan alternatif pengganti material alami seperti split atau sirtu yang biasa digunakan dalam proyek pembangunan jalan. Sejauh yang diamati penulis, bahwa puing benda uji dari hasil crushing test pada saat ini masih dianggap sebagai sampah dan belum dimanfaatkan secara efektif, karena pada saat ini puing tersebut baru bisa dimanfaatkan sebagai urugan untuk tanah.

Dari hasil survei dan wawancara yang dilakukan penulis terhadap sebuah perusahaan readymix beton di Jakarta, yaitu PT. Jaya Readymix di Kebon Nanas bahwa pada tiap laboratorium dimiliki oleh PT. Jaya Readymix menghasilkan limbah sisa dari crushing test dalam jumlah yang relatif besar yaitu rata-rata bisa menghasilkan 100 benda uji perhari. Sedangkan PT. Jaya Readymix mempunyai 6 Laboratorium yang ada di Jakarta yang tersebar di daerah Gandaria, Jelambar, Serpong, Cikarang, Cikampek dan Kebon Nanas.

Dengan melihat fenomena tersebut, maka kemungkinan mendaur ulang puing bangunan menjadi salah satu bahan material dalam pembuatan jalan bisa menjadi salah satu solusi masalah di atas. Kemungkinan pemakaian bahan puing beton tersebut adalah sebagai bahan lapis perkerasan jalan raya. Karena pada saat ini kebutuhan akan sarana transportasi yang meningkat berdampak pada semakin meningkatnya kebutuhan akan material bahan bangunan sebagai bahan lapis perkerasan pada pembuatan jalan raya.

Kemungkinan pemanfaatan puing beton tersebut sebagai bahan lapis perkerasan pada jalan raya adalah sebagai bahan lapis pondasi atas (base course). Hal ini dimungkinkan karena adanya kemiripan karakteristik antara bahan yang biasa digunakan sebagai lapis pondasi atas (base course) dengan karakteristik puing beton. Dilihat dari ciri puing beton yang mempunyai karakteristik sangat baik diantaranya adalah dari sifat fisiknya yang keras dan tahan terhadap air, memiliki gradasi yang beraneka ragam dan memiliki daya serap air yang relatif kecil. 
Dalam penelitian ini, penulis akan menggunakan kapur sebagai bahan campuran dari konstruksi lapis pondasi atas (base course), hal ini mengacu pada penelitian sebelumnya dilakukan oleh Ibrahim Imron yaitu penggunaan batuan jenis Tufa Breksi Andesit (TBA) dan kapur sebagai bahan lapis perkerasan atas (base course) jalan. Bahan kapur ini sering dipakai pada konstruksi lapis perkerasan pondasi atas (base course) sebagai bahan campuran sekaligus bahan pengisi rongga (filler) pada material agregat. Di alam biasanya kapur selalu bercampur dengan bahan lain membentuk sejenis batuan misalnya marmer, kulit kerang batu kapur dan batu dolmite $\left(\mathrm{CaSO}_{3}+\mathrm{MgCO}_{3}\right)$. Hasil pembakaran batu kapur inilah yang kemudian dikenal sebagai kapur.

Dengan pemanfaatan puing beton sebagai bahan lapis perkerasan jalan pada lapis pondasi atas (base course) diharapkan dapat menggantikan bahan baku yang biasa digunakan seperti batu spleet atau batu pecah/sirtu yang persediannya semakin terbatas. Dalam hal ini penulis ingin meneliti pengaruh penggunaan puing beton dan kapur sebagai alternatif pengganti dari penggunaan batu pecah/sirtu. Dengan demikian jika suatu saat nanti persediaan batu pecah maupun kerikil sulit diperoleh atau harganya yang cukup mahal, maka dengan penelitian ini diharapkan dapat memperoleh alternatif baru yaitu puing beton sebagai bahan pengganti agregat kasar berupa batu pecah/sirtu yang biasa dipakai sebagai bahan lapis perkerasan pada lapis pondasi atas (base course).

\section{METODA}

Tujuan penelitian benda uji campuran puing beton dengan kapur ini adalah : 1) Untuk mengetahui perbedaan nilai CBR sebagai lapis pondasi atas (base course) dengan variasi puing beton $100 \%$, puing beton $90 \%$ dan kapur $10 \%$, puing beton $87,5 \%$ dan kapur $12,5 \%$, puing beton $85 \%$ dan kapur 15\%. 2) Untuk mengetahui nilai CBR optimum bahan lapis pondasi atas (base course) dari campuran puing beton dan kapur yang memenuhi nilai CBR standar Bina Marga $(80 \%)$

Penelitian ini dilaksanakan di Laboratorium Tanah dan Jalan Dinas Pekerjaan Umum DKI Jakarta jalan May. Jend. DI Pandjaitan Persil 583 Jakarta Timur. Waktu pelaksanaan adalah semester genap tahun akademik 2006/2007. 


\section{Desain Penelitian}

Berdasarkan tujuan penelitian di atas, maka desain penelitian ini termasuk metode eksperimen di laboratorium.

Variabel yang digunakan pada penelitian ini dikelompokkan atas dua variabel, yaitu :

a. Variabel bebas penelitian adalah campuran puing beton dan kapur sebagai bahan lapis pondasi atas (base course) dengan variasi puing beton 100\%, puing beton $90 \%$ dan kapur $10 \%$, puing beton $87,5 \%$ dan kapur $12,5 \%$, puing beton $85 \%$ dan kapur $15 \%$.

b. Variabel terikat penelitian adalah nilai CBR pada masing-masing campuran puing beton dan kapur.

Yang menjadi populasi pada penelitian ini adalah nilai CBR lapisan pondasi atas (base course) dengan variasi puing beton $100 \%$, puing beton $90 \%$ dan kapur $10 \%$, puing beton $87,5 \%$ dan kapur $12,5 \%$, puing beton $85 \%$ dan kapur $15 \%$

Sampel penelitian ini adalah sampel yang meliputi kelompok benda uji material puing beton dan kapur sebanyak 16 buah sampel dengan rincian sebagai berikut :

- 4 contoh bahan puing beton tanpa pencampuran kapur

- 4 contoh bahan puing beton dan kapur dengan persentase campuran $90 \%$ puing beton dan kapur $10 \%$

- 4 contoh bahan puing beton dan kapur dengan persentase campuran $87,5 \%$ puing beton dan kapur $12,5 \%$

- 4 contoh bahan puing beton dan kapur dengan persentase campuran $85 \%$ puing beton dan kapur $15 \%$

Instrumen yang digunakan dalam penelitian ini adalah seperangkat alat Uji CBR laboratorium serta daftar isian hasil pengamatan yang meliputi kadar air, berat jenis, nalisa saringan, Los angles Abration, pemadatan berat dan nilai CBR.

\section{Prosedur Pelaksanaan Penelitian}

Tahap penelitian terbagi menjadi tiga tahap, pertama adalah tahap persiapan dan pemeriksaan bahan, kedua yaitu tahap pembuatan campuran kapur dengan puing beton yang dilakukan uji 
pemadatan untuk mendapatkan kadar air optimum, ketiga yaitu pengujian CBR laboratorium dengan berbagai variasi campuran puing beton dan kapur $0 \%, 10 \%, 12,5 \%$ dan $15 \%$. Pengujian nilai CBR laboratorium dilaksanakan berdasarkan SNI 03-1744-1989 (Pengujian CBR Laboratorium).

\section{Teknik Analisis Data}

Data penelitian yang diperoleh terlebih dahulu dilakukan persyaratan pengujian normalitas dan homogenitas. Untuk Uji normalitas digunakan uji lillifors, jika $L_{0}<L_{\text {tabel }}$ maka data tersebut berdistribusi normal. Untuk Uji Homogenitas digunakan uji Bartlett, jika $x^{2}$ hitung $<x^{2}$ tabel maka data tersebut adalah homogen.

Selanjutnya pengujian hipotesis dilakukan dengan cara uji Analisis Varian (ANAVA) dan uji t ratarata satu pihak.

\section{Hipotesis Statistik}

Hipotesis statistik pertama penelitian ini adalah :

Ho : $\mu \mathrm{a}=\mu b=\mu \mathrm{c}=\mu \mathrm{d}$

H1 : Salah satu tanda "=" tidak berlaku

Keterangan :

Ha : $\quad$ Rata-rata nilai CBR bahan lapis pondasi atas dengan $100 \%$ puing beton dan kapur $0 \%$

$\mu \mathrm{b} \quad$ : $\quad$ Rata-rata nilai CBR bahan lapis pondasi atas dengan $90 \%$ puing beton dan kapur $10 \%$

HC : $\quad$ Rata-rata nilai CBR bahan lapis pondasi atas dengan $87,5 \%$ puing beton dan kapur $12,5 \%$

$\mu \mathrm{d} \quad$ : $\quad$ Rata-rata nilai CBR bahan lapis pondasi atas dengan $85 \%$ puing beton dan kapur $15 \%$

Hipotesis statistik kedua penelitian ini adalah :

$$
\begin{aligned}
& \text { Ho : } \mu \mathrm{a}=80 \% \\
& \text { H1 }: \mu \mathrm{a}>80 \%
\end{aligned}
$$


Keterangan :

$\mu a=$ Rata-rata nilai CBR optimum bahan lapis

pondasi atas (base course) masing-masing

campuran puing beton dan kapur

\section{HASIL DAN PEMBAHASAN}

\section{Deskripsi Data}

Untuk mengetahui contoh material puing beton yang akan diuji, terlebih dahulu dilakukan penelitian pendahuluan yang maksudnya untuk mengetahui sifat-sifat material puing beton sebelum dilakukan perlakuan terhadap contoh material. Untuk itu ada beberapa pemeriksaan yang terdiri dari : pemeriksaan analisa saringan, pemeriksaan kadar air, pemeriksaan berat jenis, pemeriksaan abrasi, pemeriksaan pemadatan modified dan pengujian benda uji dengan uji CBR Laboratorium, sedangkan bahan kapur diperiksa mengenai : berat jenis dan kadar air.

Tempat penelitian dilakukan di laboratorium Kantor Departemen Pekerjaan Umum di Jl. D.I Pandjaitan, Jakarta Timur. Sedangkan puing beton diambil dari sisa benda uji crushing test labotarorium bahan dan jalan pada tempat yang sama. Berikut ini adalah hasil penelitian yang disajikan dalam bentuk tabel. Untuk lebih jelasnya lihat data lampiran masing-masing pengujian.

\section{Pemeriksaan Analisa Saringan Puing Beton}

Pada proses analisa saringan, puing beton dibagi dalam 4 jenis fraksi, yaitu fraksi puing beton sebagai berikut :

a) Abu semen (lolos saringan no.4)

b) Screening (lolos saringan $1 / 2$ " dan tertahan no.4)

c) Spleet sedang (lolos saringan $3 / 4$ " dan tertahan $1 / 2$ ")

d) Spleet kasar (lolos saringan 11/2" tertahan saringan $3 / 4$ ")

Dari masing-masing fraksi kemudian disaring dengan menggunakan saringan menurut standar SNI 03-1968-1990. Berikut ini adalah tabel hasil pemeriksaan analisa saringan tiap fraksi. 
Tabel 3. Analisis Saringan Fraksi Abu-semen (0-5)

\begin{tabular}{|c|c|c|c|c|}
\hline & $\begin{array}{c}\text { Diatas } \\
\text { saringan }\end{array}$ & $\begin{array}{c}\text { Jumlah Kumulatif } \\
\text { diatas }\end{array}$ & $\begin{array}{l}\text { Persen } \\
\text { diatas }\end{array}$ & $\begin{array}{l}\text { Persen } \\
\text { melalui }\end{array}$ \\
\hline $11 / 2^{\prime \prime}$ & & & & \\
\hline $1^{\prime \prime}$ & & & & \\
\hline $3 / 4 "$ & & & & \\
\hline $1 / 2 \prime \prime$ & & & & \\
\hline $3 / 8^{\prime \prime}$ & & 0 & 0 & 100 \\
\hline $\mathrm{No} .4$ & 42,11 & 42,11 & 2,73 & 97,27 \\
\hline 10 & 454,49 & 496,60 & 32,20 & 67,80 \\
\hline 40 & 573,00 & 1069,60 & 69,35 & 30,65 \\
\hline 200 & 242,80 & 1312,40 & 85,09 & 14,91 \\
\hline$>200$ & 230,00 & 1542,40 & 100 & \\
\hline
\end{tabular}

Tabel 4. Analisis Saringan Fraksi Screening (5-10)

\begin{tabular}{|c|c|c|c|c|}
\hline & \multicolumn{4}{|c|}{ Berat contoh : $2.024,7$ gram } \\
\hline & $\begin{array}{c}\text { Diatas } \\
\text { saringan }\end{array}$ & $\begin{array}{c}\text { Jumlah Kumulatif } \\
\text { diatas }\end{array}$ & $\begin{array}{l}\text { Persen } \\
\text { diatas }\end{array}$ & $\begin{array}{l}\text { Persen } \\
\text { melalui }\end{array}$ \\
\hline $1 \frac{1}{2}{ }^{\prime \prime}$ & & & & \\
\hline $1^{\prime \prime}$ & & & & \\
\hline $3 / 4 "$ & & & & \\
\hline $1 / 2 " 1$ & 0 & 0 & 0 & 100 \\
\hline $3 / 8^{\prime \prime}$ & 760,60 & 760,60 & 37,57 & 62,43 \\
\hline No. 4 & 1121,40 & 1882,00 & 92,95 & 7,05 \\
\hline 10 & 131,40 & 2013,40 & 99,44 & 0,56 \\
\hline 40 & 4,80 & 2018,20 & 99,68 & 0,32 \\
\hline 200 & 4,00 & 2022,20 & 99,88 & 0,12 \\
\hline$>200$ & 2,50 & 2024,70 & 100 & 0 \\
\hline
\end{tabular}


Tabel 5. Analisis Saringan Fraksi Spleet Sedang (10-30)

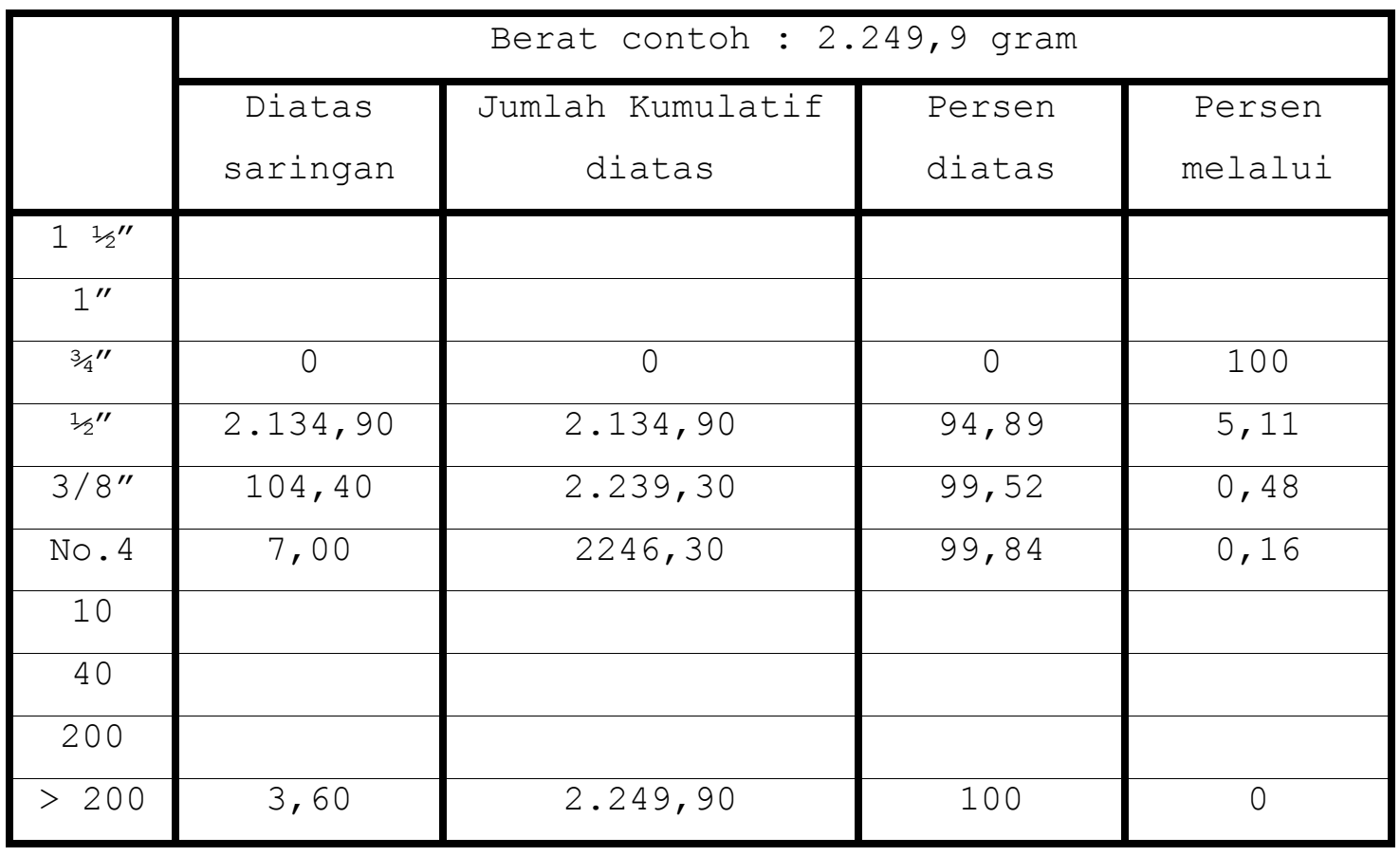

Tabel 6. Analisis Saringan Fraksi Spleet Kasar (30-50)

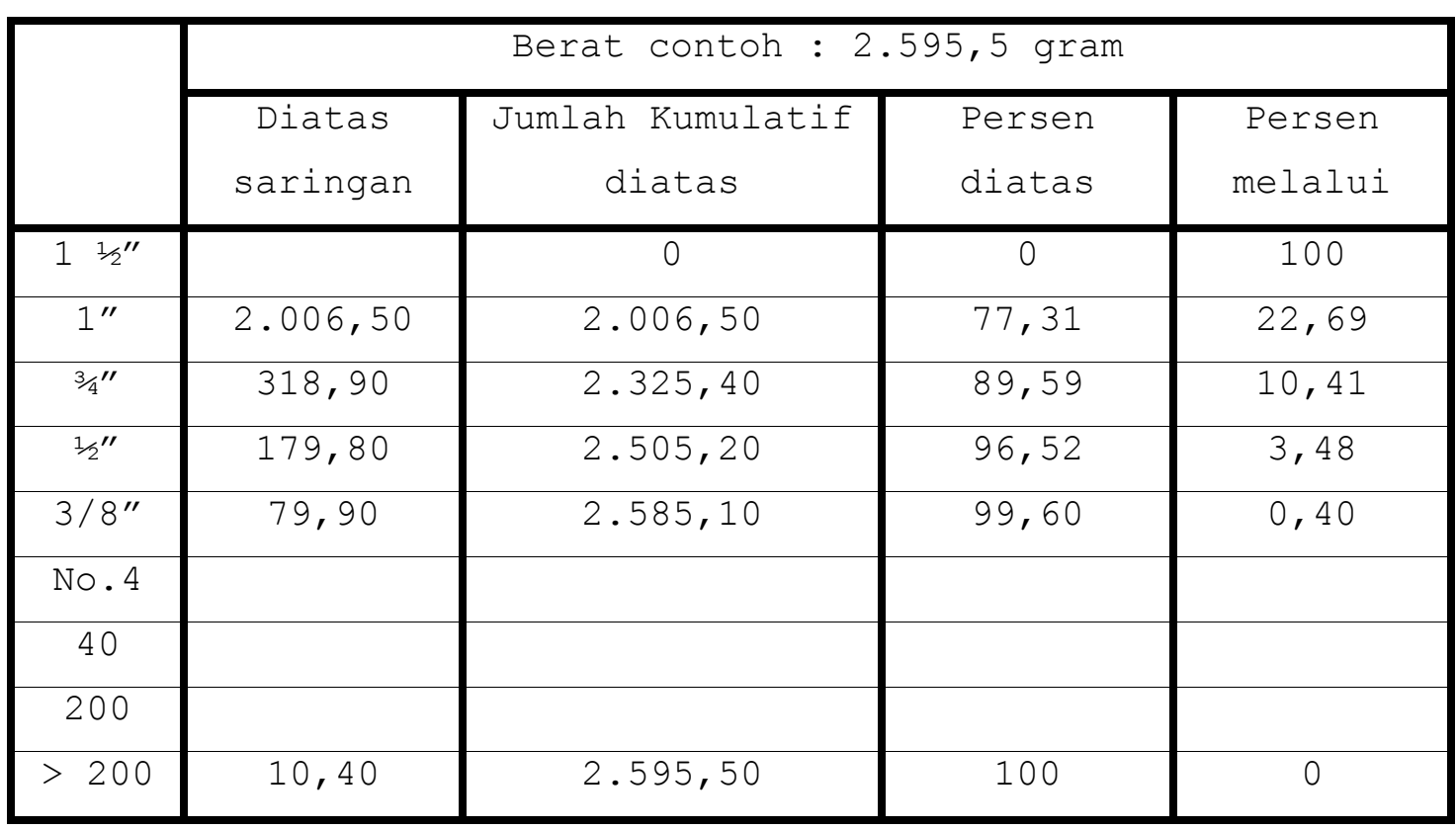

Dari hasil pemeriksaan analisis saringan tiap fraksi, kemudian dikombinasikan (lihat lampiran perhitungan komposisi agregat hal. 90). Dari hasil kombinasi tiap fraksi tersebut didapat perbandingan komposisi tiap fraksi untuk mendapatkan gradasi agregat yang dikehendaki yaitu komposisi agregat class A seperti berikut : 
Tabel 7. Gradasi Kombinasi Agregat Class A

\begin{tabular}{|c|c|c|c|c|c|c|c|c|c|c|}
\hline \multirow{2}{*}{$\begin{array}{c}\text { No } \\
\text { Sieve }\end{array}$} & \multicolumn{4}{|c|}{ Agregat Melalui } & \multicolumn{3}{c|}{ Perbandingan agg (\%) } & \multirow{2}{*}{ Hasil } & \multirow{2}{*}{ Spec } \\
\cline { 2 - 10 } & $\mathbf{0 - 5}$ & $\mathbf{5 - 1 0}$ & $\mathbf{1 0 - 3 0}$ & $\mathbf{3 0 - 5 0}$ & $\mathbf{3 6}$ & $\mathbf{2 0}$ & $\mathbf{2 0}$ & $\mathbf{2 4}$ & & \\
\hline $1^{1 / 2 \prime \prime}$ & 100 & 100 & 100 & 100 & 36 & 20 & 20 & 24 & 100 & 100 \\
\hline $1^{\prime \prime}$ & 100 & 100 & 100 & 22,69 & 36 & 20 & 20 & 5,45 & 81,45 & $77-85$ \\
\hline $3 / 8^{\prime \prime}$ & 100 & 62,43 & 0,48 & 0,40 & 36 & 12,49 & 0,10 & 0,10 & 48,69 & $44-58$ \\
\hline No.4 & 97,27 & 7,05 & 0,16 & & 35,02 & 1,41 & 0,03 & & 36,46 & $27-44$ \\
\hline 10 & 67,8 & 0,56 & & & 24,41 & 0,11 & & & 24,52 & $17-30$ \\
\hline 40 & 30,65 & 0,32 & & & 11,03 & 0,06 & & & 11,09 & $7-17$ \\
\hline 200 & 14,91 & 0,12 & & & 5,37 & 0,02 & & & 5,39 & $2-8$ \\
\hline
\end{tabular}

Pemeriksaan Kadar Air Puing Beton

Tabel 8. Hasil Pemeriksaan Kadar Air Puing Beton

\begin{tabular}{|c|c|}
\hline Bahan & Kadar Air \\
\hline Puing Beton & $4,85 \%$ \\
\hline
\end{tabular}

Pemeriksaan Berat Jenis Puing Beton

Karena agregat puing beton berupa campuran dari agregat kasar dan halus, maka dalam mencari berat jenis gabungan diperoleh dengan cara mencari berat jenis kedua jenis agregat. Agregat kasar yaitu ageregat yang tertahan saringan no.4, sedangkan agregat halus yaitu agregat yang lolos saringan no.4.

Dari hasil penelitian diperoleh berat jenis puing beton agregat $\mathrm{kasar}=2,51 \mathrm{gr} / \mathrm{cc}$ dan agregat halus $=2,38 \mathrm{gr} / \mathrm{cc}$. Dengan demikian berat jenis agregat gabungan dapat dihitung sebagai berikut :

berat jenis agregat gabungan dapat dihituna sebaaai berikut :

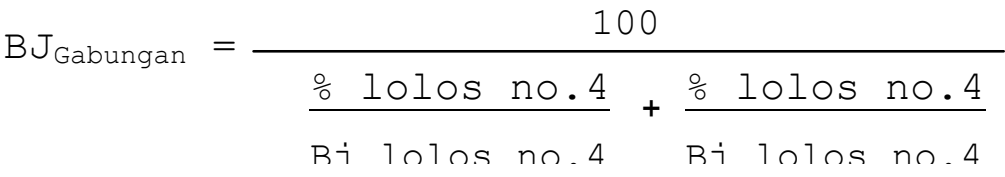

$$
\begin{aligned}
& \mathrm{BJ}_{\text {Gabungan }}=\frac{100}{\frac{36,78}{2,38}+\frac{63,22}{2,51}} \quad=2,46
\end{aligned}
$$


Tabel 9. Hasil Pemeriksaan Berat Jenis Puing Beton

\begin{tabular}{|c|c|}
\hline Bahan & Berat Jenis (gr/cc) \\
\hline Puing Beton & 2,46 \\
\hline
\end{tabular}

Pemeriksaan Keausan Puing Beton

Tabel 10. Hasil Pemeriksaan Keausan Puing Beton

\begin{tabular}{|c|c|}
\hline Bahan & \% Keausan \\
\hline Puing Beton & $39,2 \%$ \\
\hline
\end{tabular}

Pemeriksaan Berat Jenis Bahan Kapur

Tabel 11. Hasil Pemeriksaan Berat Jenis Kapur

\begin{tabular}{|c|c|}
\hline Bahan & Berat Jenis \\
\hline Kapur & 2,03 \\
\hline
\end{tabular}

Pemeriksaan Kadar Air Kapur

Tabel 12. Hasil Pemeriksaan Kadar Air Kapur

\begin{tabular}{|c|c|}
\hline Bahan & Kadar Air \\
\hline Kapur & $33,14 \%$ \\
\hline
\end{tabular}

Dari data tersebut di atas kemudian ditentukan komposisi pencampuran Puing Beton dan Kapur dengan kadar air tertentu, untuk selanjutnya dilakukan pengujian proctor dan CBR.

Tabel 13. Hasil Pengujian Pemadatan (proctor) puing dan kapur

\begin{tabular}{|l|c|c|c|c|}
\hline \multicolumn{1}{|c|}{ Variasi bahan } & $\begin{array}{c}\text { Kadar air } \\
\text { awal } \\
(\%)\end{array}$ & $\begin{array}{c}\text { Berat } \\
\text { Jenis }\end{array}$ & $\begin{array}{c}\text { Yd } \\
\left(\mathbf{t} / \mathrm{m}^{3}\right)\end{array}$ & $\begin{array}{c}\text { Kadar air } \\
\text { optimum } \\
(\%)\end{array}$ \\
\hline A (Puing 100\%) & 4,85 & 2,46 & 1.805 & 12,10 \\
\hline
\end{tabular}




\begin{tabular}{|l|l|l|l|l|}
\hline B (Puing 90\% + Kapur 10\%) & 6,03 & 2,44 & 1.710 & 14,20 \\
\hline C (Puing 87,5\% + Kapur 12,5\%) & 6,04 & 2,43 & 1.695 & 14,10 \\
\hline D (Puing 85\% + Kapur 15\%) & 6,08 & 2.41 & 1.675 & 14,50 \\
\hline
\end{tabular}

Tabel 14. Hasil Pengujian CBR puing beton dan kapur

\begin{tabular}{|l|c|c|}
\hline \multicolumn{1}{|c|}{ Variasi Bahan } & $\begin{array}{c}\text { Kadar Air } \\
\text { Optimum }\end{array}$ & $\begin{array}{c}\text { California Bearing } \\
\text { Ratio (CBR) } \\
\text { (\%) }\end{array}$ \\
\hline A (Puing 100\%) & 11,90 & 51,875 \\
\hline B (Puing 90\% + Kapur 10\%) & 13,10 & 60,375 \\
\hline C (Puing 87,5\% + Kapur 12,5\%) & 13,40 & 68,125 \\
\hline D (Puing 85\% + Kapur 15\%) & 14,20 & 81,375 \\
\hline
\end{tabular}

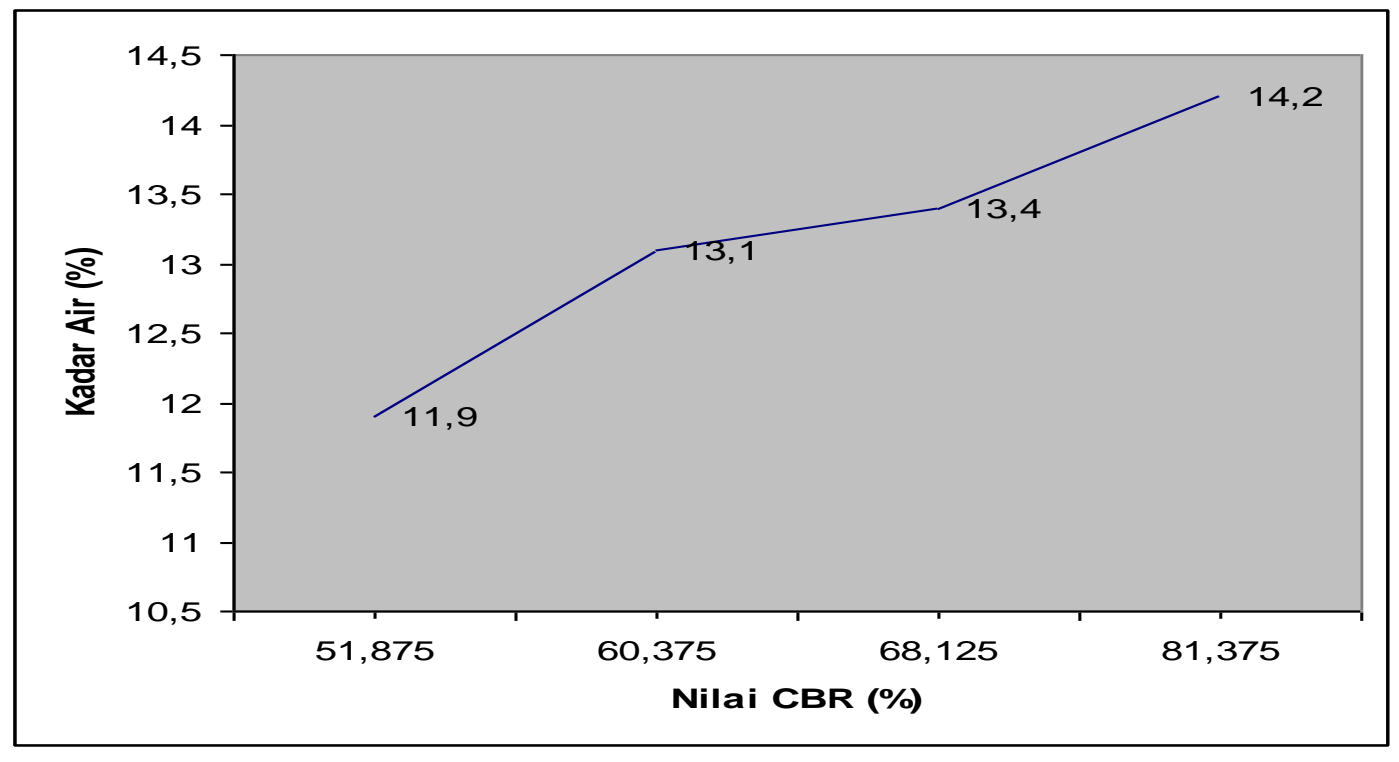

Grafik Hubungan Antara Kadar Air Dengan Nilai CBR

Dari tabel dan grafik di atas terlihat bahwa variasi penambahan kapur meningkatkan kadar air optimum tiap variasi. Hasil pengujian menunjukkan bahwa dengan kadar air optimum yang meningkat, terlihat juga peningkatan nilai CBR tiap variasi. Nilai CBR variasi $A$ lebih rendah dari variasi $B$, variasi $B$ lebih rendah dari variasi $C$, variasi $C$ lebih rendah dari variasi $D$. 
Tabel 15. Perbandingan Nilai CBR Puing dan Kapur Terhadap NilaiPemadatan.

\begin{tabular}{|l|c|c|}
\hline \multicolumn{1}{|c|}{ Variasi Bahan } & $\begin{array}{c}\text { Kepadatan } \\
\mathrm{Yd}_{\mathrm{d}}\left(\mathrm{t} / \mathrm{m}^{3}\right)\end{array}$ & $\begin{array}{c}\text { California Bearing } \\
\text { Ratio (CBR) } \\
\text { (\%) }\end{array}$ \\
\hline A (Puing 100\%) & 1.805 & 51,875 \\
\hline B (Puing 90\% + Kapur 10\%) & 1.710 & 60,375 \\
\hline C (Puing 87,5\% + Kapur 12,5\%) & 1.695 & 68,125 \\
\hline D (Puing 85\% + Kapur 15\%) & 1.675 & 81,375 \\
\hline
\end{tabular}

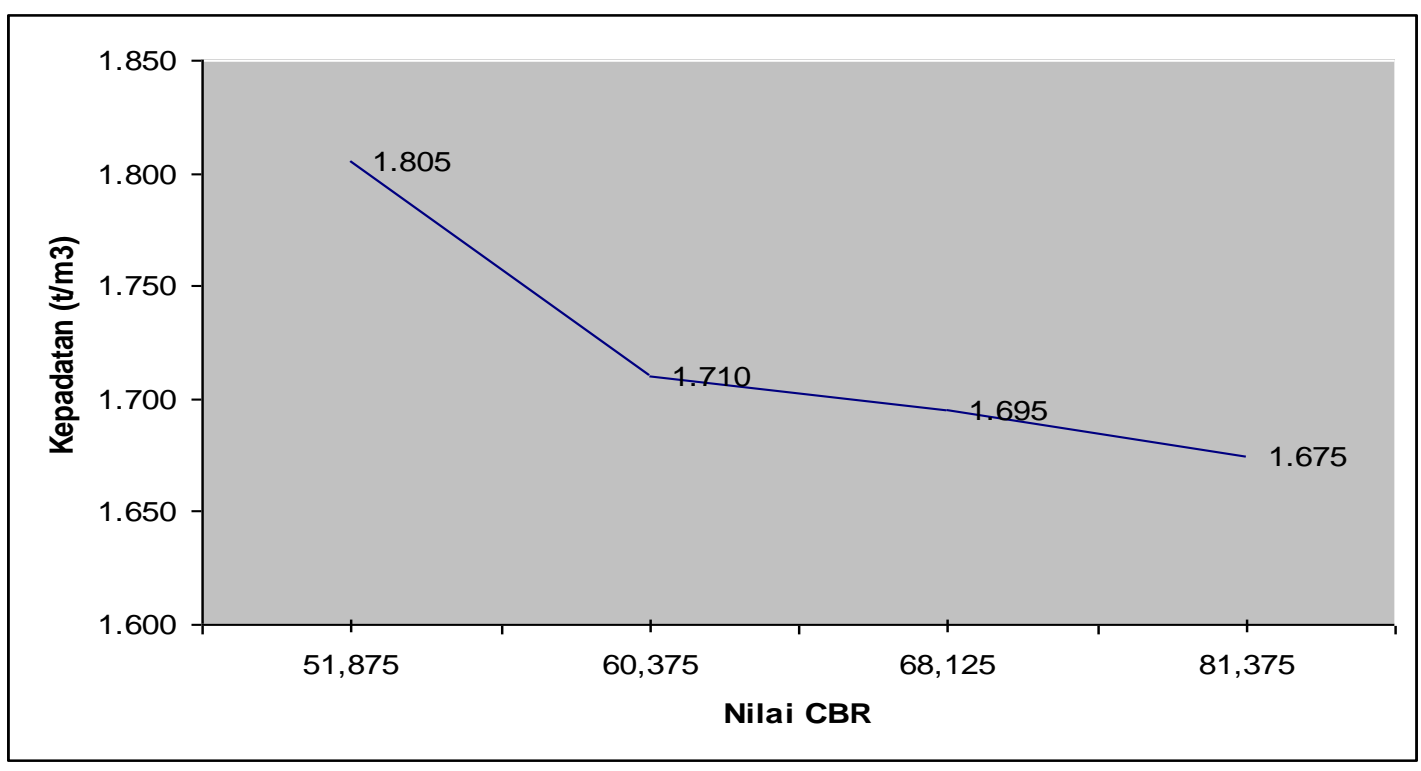

Grafik Hubungan Antara Nilai Kepadatan dan Nilai CBR

Dari tabel dan grafik di atas, menunjukkan bahwa penambahan kapur menurunkan nilai kepadatan tiap variasi, sementara itu dari nilai kepadatan yang semakin rendah diperoleh nilai CBR yang semakin meningkat.

\section{Pengujian Persyaratan Analisis Data}

\section{Uji Normalitas}

Pada pengujian normalitas data dianalisa dengan menggunakan uji liliefors. Data yang dianalisa adalah data hasil percobaan nilai CBR. 
a. Uji Normalitas Data Nilai CBR Untuk Perlakuan A (Puing 100\%)

Hasil analisa data yang diperoleh dengan uji liliefors adalah nilai Lo $=-0,0934$. Berdasarkan tabel nilai kristis uji liliefors untuk $n$ (sampel) $=4$ dan taraf $\operatorname{signifikan~}(\alpha)=0,01$ ) diperoleh data $L_{\text {tabel }}=$ 0,417 , maka Lo < $L_{\text {tabel }}$ (analisa dapat dilihat pada lampiran perhitungan uji normalitas). Kesimpulan dari hasil analisa adalah adalah bahwa nilai CBR yang diperoleh berdistribusi normal.

b. Uji Normalitas Data Nilai CBR Untuk Perlakuan B (Puing 90\% + Kapur 10\%)

Hasil analisa data yang diperoleh dengan uji liliefors adalah nilai Lo $=-0,0323$. Berdasarkan tabel nilai kristis uji liliefors untuk $n$ (sampel) $=4$ dan taraf signifikan $(\alpha)=0,01$ ) diperoleh data $L_{\text {tabel }}=$ 0,417, maka Lo < Ltabel (analisa dapat dilihat pada lampiran perhitungan uji normalitas). Kesimpulan dari hasil analisa adalah adalah bahwa nilai CBR yang diperoleh berdistribusi normal.

C. Uji Normalitas Data Nilai CBR Untuk Perlakuan C (Puing 87,5\% + Kapur 12,5\%)

Hasil analisa data yang diperoleh dengan uji liliefors adalah nilai Lo $=-0,0551$. Berdasarkan tabel nilai kristis uji liliefors untuk $n$ (sampel) $=4$ dan taraf $\operatorname{signifikan~}(\alpha)=0,01$ ) diperoleh data $L_{\text {tabel }}=$ 0,417, maka Lo < Ltabel (analisa dapat dilihat pada lampiran perhitungan uji normalitas). Kesimpulan dari hasil analisa adalah adalah bahwa nilai CBR yang diperoleh berdistribusi normal.

d. Uji Normalitas Data Nilai CBR Untuk Perlakuan D (Puing 85\% + Kapur 15\%)

Hasil analisa data yang diperoleh dengan uji liliefors adalah nilai Lo $=-0,0323$. Berdasarkan tabel nilai kristis uji liliefors untuk $n$ (sampel) $=4$ dan taraf signifikan $(\alpha)=0,01$ ) diperoleh data $L_{\text {tabel }}=$ 0,417, maka Lo < Ltabel (analisa dapat dilihat pada lampiran perhitungan uji normalitas). Kesimpulan dari hasil analisa adalah adalah bahwa nilai CBR yang diperoleh berdistribusi normal.

Berikut ini adalah tabel data hasil uji normalitas : 
Tabel 16. Hasil Uji Normalitas

\begin{tabular}{|c|c|c|c|c|c|}
\hline & Variasi Bahan & $\mathbf{N}$ & $\mathbf{L}_{\text {hitung }}$ & $\mathrm{L}_{\text {tabel }}$ & Kesimpulan \\
\hline A & (Puing 100\%) & 4 & $-0,0934$ & 0,417 & $\begin{array}{c}\text { Lo }<\mathrm{L}_{\text {Tabel }} \\
\text { Normal }\end{array}$ \\
\hline B & (Puing 90\% + Kapur 10\%) & 4 & $-0,0323$ & 0,417 & $\begin{array}{c}\text { Lo }<\mathrm{L}_{\text {Tabel }} \\
\text { Normal }\end{array}$ \\
\hline C & (Puing 87,5\% + Kapur 12,5\%) & 4 & $-0,0551$ & 0,417 & $\begin{array}{c}\text { Lo }<\mathrm{L}_{\text {Tabel }} \\
\text { Normal }\end{array}$ \\
\hline $\mathrm{D}$ & (Puing 85\% + Kapur 15\%) & 4 & $-0,0323$ & 0,417 & $\begin{array}{c}\text { Lo }<\mathrm{L}_{\text {Tabel }} \\
\text { Normal }\end{array}$ \\
\hline
\end{tabular}

Dilihat dari tabel di atas, dapat disimpulkan bahwa nilai CBR untuk seluruh perlakuan $A, B, C$, dan $\mathrm{D}$ berdistribusi normal.

\section{Uji Homogenitas}

Setelah persyaratan normalitas diperoleh, maka dilanjutkan dengan uji homogenitas dengan menggunakan uji Barlett. Berikut ini adalah tabel hasil perhitungan Uji Homogenitas :

Tabel 17. hasil Uji Homogenitas dengan Uji Barlett

\begin{tabular}{|c|c|c|c|c|}
\hline \multirow{2}{*}{$\mathbf{S}^{2}$ gabungan } & \multirow{2}{*}{ Log $\mathbf{S}^{2}$} & \multirow{2}{*}{$\mathrm{B}$} & \multicolumn{2}{|c|}{$\mathrm{X}^{2}$} \\
\cline { 4 - 5 } & & & Hitung & Tabel \\
\hline 0,729 & $-0,1373$ & $-1,6473$ & 4,3568 & 11,3 \\
\hline
\end{tabular}

Keterangan $: \mathrm{S}^{2}$ gabungan = varians gabungan dari kelompok

Dari hasil perhitungan diperoleh harga $X^{2}=4,3568$, (untuk hasil pengujian dapat dilihat pada lampiran perhitungan Uji Homogenitas). Dari daftar $\mathrm{H}$ untuk distribusi $\mathrm{X}^{2}$ maka dapat dilihat nilai chi kuadrat dalam tabel, $\mathrm{dk}=4-1=3$ dan taraf signifikan $(\alpha)=0,01$ diperoleh $\mathrm{X}^{2}$ Tabel $=11,3$, maka $X^{2}$ hitung $<X^{2}$ tabel sehingga dapat disimpulkan varians populasi homogen. 


\section{B. Pengujian Hipotesis}

\section{Hipotesis pertama}

Hipotesis nol $\left(\mathrm{H}_{0}\right)$ : Tidak ada perbedaan nilai CBR bahan lapis perkerasan atas (base course) antar variasi $100 \%$ puing, Puing $90 \%$ dan kapur $10 \%$, puing $87,5 \%$ dan kapur $12,5 \%$, puing $85 \%$ dan kapur 15\%. Untuk mendapatkan hasil pengujian digunakan uji ANAVA. Hasil analisa dapat dilihat pada tabel berikut :

Tabel 18. Hasil ANAVA Nilai CBR Bahan Lapis Pondasi Atas

\begin{tabular}{|c|c|r|r|r|r|}
\hline Sumber varians & dk & \multicolumn{1}{|c|}{$\mathbf{J k}$} & \multicolumn{1}{|c|}{$\mathbf{K T}$} & $\mathbf{F}_{\text {hitung }}$ & $\mathbf{F}_{\text {tabel }}$ \\
\hline Rata-rata & 1 & $68.513,06$ & $68.513,06$ & & \\
\hline Antar Kelompok & 3 & $1.883,19$ & 627,73 & 860,89 & 5,95 \\
\hline Dalam Kelompok & 12 & $70.405,00$ & 0,73 & & \\
\hline Jumlah & 16 & $140.801,25$ & & & \\
\hline
\end{tabular}

Keterangan :

$$
\begin{array}{ll}
\mathrm{JK} & =\text { jumlah kuadrat } \\
\mathrm{dk} & =\text { derajat kebebasan } \\
\mathrm{KT} & =\text { kuadrat tengah }
\end{array}
$$

Dari tabel di atas diketahui, yaitu pada taraf signifikan 0,01 dan dari daftar I untuk distribusi $\mathrm{F}$ didapat $F_{\text {tabel }}=5,95$ sehingga $F_{\text {hitung }}>F_{\text {tabel }}(860,89>5,95)$, dengan demikian Ho ditolak. Hasil penelitian ini menunjukan ada perbedaan signifikan dari nilai CBR untuk lapis pondasi atas (base course) dengan variasi puing beton $100 \%$, puing beton $90 \%$ dan kapur $10 \%$, puing beton $87,5 \%$ dan kapur $12,5 \%$, puing beton $85 \%$ dan kapur $15 \%$.

\section{Hipotesis kedua}

Hipotesis $\left(\mathrm{H}_{0}\right)$ : Nilai CBR bahan lapis perkerasan atas (base course) dari campuran yang optimum bahan puing beton dan kapur tidak lebih tinggi dari pada nilai CBR standar Bina Marga (80\%). Nilai CBR maksimum dicapai pada variasi D, yaitu dengan puing beton $85 \%$ dan kapur $15 \%$. 
Dengan menggunakan uji statistik student distribusi t atau uji kesaman dua rata-rata uji satu pihak analisa data dapat dilihat pada lampiran perhitungan Uji t.

Tabel 19. Hasil Uji t

\begin{tabular}{|c|c|c|c|c|c|}
\hline $\begin{array}{c}\text { Nilai CBR } \\
(\%)\end{array}$ & $\mathbf{T}_{\text {hitung }}$ & $\mathbf{d k}$ & $\boldsymbol{a}$ & $\mathbf{t}_{\text {tabel }}$ & Kesimpulan \\
\hline 81,375 & 5,74 & 3 & 0,01 & 4,54 & $\begin{array}{c}\text { Thitung }_{\text {(Ho ditolak) }} \\
\text { (Habel }\end{array}$ \\
\hline
\end{tabular}

Dari perhitungan menunjukkan besar nilai $t_{\text {hitung }}>t_{\text {tabel }}(5,74>4,54)$ maka Ho ditolak. Hasil penelitian ini menunjukkan bahwa nilai CBR bahan lapis pondasi atas (base course) dengan variasi puing beton $85 \%$ dan kapur $15 \%$ lebih tinggi dari pada nilai CBR standar Bina Marga $(80 \%)$.

\section{Pembahasan Hasil Penelitian}

Dilihat dari hasil penelitian nilai masing-masing CBR yang dilakukan mempunyai keterkaitan antara komposisi bahan, besar variasi butiran, sifat-sifat bahan, kadar air yang digunakan dan kepadatan maksimumnya. Hasil pengujian CBR dengan menggunakan puing beton dan kapur menghasilkan nilai CBR yang tinggi dengan kepadatan rendah dan kadar air tinggi, sehingga dapat disimpulkan bahwa semakin rendah kepadatannya dan semakin tinggi kadar airnya maka akan menghasilkan nilai CBR yang semakin tinggi.

Dari hasil statistik dengan menggunakan uji $t$ rata-rata satu pihak didapat thitung $>t_{\text {tabel, }}$ hal ini menunjukkan bahwa nilai CBR dengan menggunakan puing beton dan kapur lebih tinggi dari nilai CBR standar Bina Marga (80\%), dimana CBR maksimum pada penelitian ini dicapai pada komposisi puing beton $85 \%$ dan kapur $15 \%$.

Penggunaan kapur pada campuran puing beton terbukti mampu meningkatkan nilai CBR secara signifikan, hal ini karena kapur berfungsi sebagai pengisi rongga, sehingga antara butiran dapat terisi dengan sempurna dengan demikian dapat memperingan proses pemadatannya.

Dari hasil penelitian uji kepadatan dimana semakin tinggi kepadatannya, maka akan semakin rendah kadar airnya. Sedangkan nilai CBR yang tinggi diperoleh dari pemadatan rendah dan kadar air yang tinggi. Sehingga dapat disimpulkan bahwa penggunaan puing dan kapur 
menghasilkan nilai CBR yang tinggi dengan pemadatan yang rendah dan kadar air yang tinggi. Kadar air tinggi disebabkan karena sifat kapur yang mempunyai daya serap air yang sangat tinggi.

\section{KESIMPULAN}

Dari hasil penelitian didapat bahwa nilai CBR dengan menggunakan puing beton dan kapur dengan variasi $85 \%$ puing dan 15\% kapur lebih tinggi dari nilai CBR standar Bina Marga yaitu $80 \%$, berdasarkan hasil penelitian tersebut maka dapat disimpulkan :

1. Material puing beton dapat digunakan sebagai bahan pengganti batu pecah/sirtu pada lapisan pondasi atas (base course) jalan.

2. Dengan pemakaian kapur sebagai bahan campuran puing beton pada lapis pondasi atas (base course) jalan, terbukti dapat meningkatkan nilai CBR.

3. Untuk memperoleh nilai CBR yang tinggi diperlukan bahan-bahan yang berkualitas dan memenuhi syarat baik secara fisik maupun mutu gradasi dari bahan tersebut.

\section{DAFTAR PUSTAKA}

Aly, Moh. Anas, Perencanaan Perkerasan Jalan Raya.Jakarta: Departemen Pekerjaan Umum, 1983.

Departemen Pekerjaan Umum, Persyaratan Umum Bahan Bangunan di Indonesia. Jakarta: Badan Penerbit Departemen Pekerjaan Umum, 1986.

Departemen Pekerjaan Umum, Spesifikasi Umum Bidang Jalan dan Jembatan. Jakarta: Pusat Litbang Prasarana Transportasi Badan Penelitian dan Pengembangan, 2005.

Departemen Pendidikan dan Kebudayaan. Kamus Besar Bahasa Indonesia. Jakarta: Balai Pustaka, 1990.

Departemen Permukiman dan Prasarana Wilayah. Metode Spesifikasi dan Tata Cara edisi Pertama, Desember 2002. Badan Penelitian dan Pengembangan, 2002.

Dipohusodo, Istimawan. Struktur Beton Bertulang, cetakan kedua. Jakarta: PT.Gramedia Pustaka Utama, 1996.

Hendarmin, HR Affandy. Jalan Raya. Jakarta: Bursa Buku 1985.

National Association of Australian State Road Authorities, Principles and Practice of Bituminous Surfacing volume II. Melbourne: Plant Mix Work press, 1968. 
Nurlelly, Asmaul Husna dan Azmeri. Analisa Soil Cement Sebagai Pengganti Lapisan Perkerasan sub-base Jalan Kelas A/B. Aceh: Laporan Penelitian Fakultas Teknik Syah Kuala, 1999.

Oglesby, Clarkson H., R. Gary Hicks, Teknik Jalan Raya terjemahan Purwo Setianto. Jakarta : Penerbit Erlangga, 1996.

Soedarsono, Djoko Untung. Konstruksi Jalan Raya. Jakarta: Badan Penerbit Pekerjaan Umum, 1985.

Standar Nasional Indonesia. Metode Pengujian CBR Laboratorium. Jakarta: Badan Standarisasi Nasional,1989.

Sudjana MA, Metode Statistika, Bandung: Tarsito, 1983.

Supribadi, IK, IImu Bangunan Gedung Seri A Bangunan Sipil. Bandung: Armico, 1985.

Wallace, Huge A, Martins J.R, Asphalt Pavement Engineering. New York: Mc Graw-Hill Book Company, 1967. 